\title{
Effect of Refiner Plate Pattern Design on Refined Fibre Size Distribution - a Time Series Study
}

\section{Utjecaj dizajna diskova za razvlaknjivanje na raspodjelu veličina proizvedenih vlakana - analiza vremenskog niza}

\author{
Professional paper • Stručni rad \\ Received-prispjelo: 19. 12. 2013. \\ Accepted-prihvaćeno: 14. 1. 2015. \\ UDK: $630 * 861.231 ; 630 * 862.2$ \\ doi:10.5552/drind.2015.1368
}

\begin{abstract}
In a multi-step batch or continuous operating process, quantitative \& qualitative optimization of every single step is always aimed at. Even the smallest aberration in processing parameters affects the quality of the final product. Therefore, it is necessary to study time series quality of products delivered by every single step, so as to ensure product quality in a long run. Refining is one of the most crucial steps in fibreboard manufacturing, as it has a major impact on fibre quality and energy consumption. Refining plate pattern is key to good results, which have to be optimized based on experience or onsite testing. We tested three different refining plate patterns: straight bar design pattern (TYPE 1), spiral bars design pattern (TYPE 2) and bar with groove pattern (TYPE 3), and their impact on fibre size quality in a time series. Reported results include fibre size distribution of three different types of plate patterns observed for 1500 hrs and relative quantity of fine fibres observed in time series for three variants of disc type refiners. Our research showed that fibre quality within desired limits was best delivered by TYPE 2 plates; however, fibre quality also varied with time series for three of them, so different time periods of desired fibre quality were analysed.
\end{abstract}

Key words: refining plate pattern, fibre size quality, disc type refiner

SAŽETAK・U procesu sastavljenome od više kraćih faza ili u kontinuiranome operativnom procesu kvantitativna i kvalitativna optimizacija usmjerena je na svaku pojedinu fazu. Čak i vrlo malo odstupanje parametara obrade utječe na kvalitetu konačnog proizvoda. Stoga je kvalitetu proizvoda u realnom vremenu potrebno pratiti u svakoj fazi proizvodnje kako bi se dugoročno osigurala kvaliteta proizvoda. Razvlaknjivanje je jedna od najvažnijih faza u proizvodnji ploča vlaknatica jer ima velik utjecaj na kvalitetu vlakana i potrošnju energije. Dizajn diska mlina za razvlaknjivanje ključan je za dobar rezultat te njegov dizajn mora biti optimiziran na temelju iskustva ili na temelju rezultata istraživanja u pogonu. U radu se prikazuju rezultati ispitivanja triju različitih dizajna ploča za razvlaknjivanje: ploča s ravnim trakama (TYPE 1), ploča sa spiralnim trakama (TYPE 2) i ploča s trakama s utorom (TYPE 3) te njihov utjecaj na kvalitetu vlakana s obzirom na dimenzije u vremenskom nizu. Predstavljeni rezultati obuhvaćaju distribuciju veličine vlakana dobivenih primjenom triju različitih vrsta ploča za razvlaknjivanje tijekom 1500 sati i relativne količine finih vlakana promatranih u vremenskom nizu za tri varijante ploča za raz-

\footnotetext{
Authors are associated professor and assistants at Mendel University in Brno, Faculty of Forestry and Wood Technology, Brno, Czech Republic.

Autori su izvanredni profesor i asistenti Mendelova sveučilišta u Brnu, Fakultet šumarstva i drvne tehnologije, Brno, Republika Češka.
} 
vlaknjivanje. Uočeno je da se najbolja kvaliteta vlakana u željenim veličinama postiže primjenom ploče TYPE 2 , no kvaliteta vlakana mijenja se u vremenskom nizu, a analizirana su različita vremenska razdoblja u kojima se postiže željena kvaliteta vlakana.

Ključne riječi: dizajn ploče za razvlaknjivanje, kvaliteta veličine vlakana, vrsta diskova za razvlaknjivanje

\section{INTRODUCTION}

\section{UVOD}

Hydrothermal refining is the process of converting steamed chips into fibre bundles, widely utilized in fibre board and pulping industries (Lumiainen, 2010). Factors affecting the choice of a refiner can be divided into two categories, first refiner considerations and second system considerations. Refiner considerations include plate diameter, pattern design detail, surface and sub-surface dams, refining intensity (fibre type) and alloy. System considerations include refiner throughput, system stability, stock contamination, available horsepower, operating scheme, and control method. Refining plate pattern is the criteria affecting energy consumption as well as fibre size quality. That is why refiner plate pattern is continuously researched and improved. Plate pattern has changed from classical constant angle type and bar with groove type to more advanced and improved types, for example curved refining bars with jagged leading sidewalls (Gingras, 2011), plates with logarithmic spiral type bars (Antensteiner, 2008), damless refiner plate for wood fibres (Savujz'irvi and Liifgren,1999), rough edged refiner plate cutter bars (Wasikowski,1996), tooth refiner plates having V-shaped teeth (Gingras, 2012). Despite the efforts to find a computer model to design plates, in the end the selection is based on experience and onsite testing of the process (Rowell, 2012).

The refiner plate design is characterized by bar width $(b)$, groove width $(g)$, groove depth $(g d)$, sector angle $(q)$, and bar angle $(f)$; plate designs are typically characterized by the length of intersecting edges between the opposing plates, termed as the "bar edge length" (BEL) (Figure 1).

$B E L$ is a standardized measure in the industry estimated using TAPPI standard TIP 0508-05 (1994):Eq.(1)

$$
B E L=\int_{R 2}^{R 1} \frac{n_{\mathrm{r}}(r) \cdot n_{\mathrm{s}}(r)}{\cos \phi} d r
$$

Where $n_{\mathrm{r}}(r)$ and $n_{\mathrm{s}}(r)$ are the number of bars on the rotor and stator plate at a given radius, $R_{1}$ and $R_{2}$ are the inner and outer radii of the refiner plates, respectively.

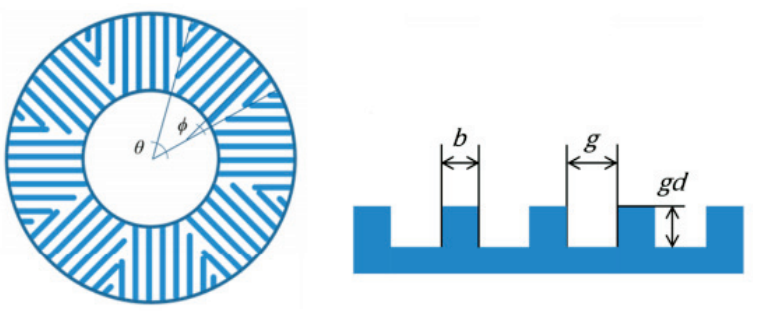

Figure 1 Characteristic features of a refiner plate Slika 1. Karakteristična obilježja ploča za razvlaknjivanje
To approximate this integral, the number of bars on each plate can be roughly estimated by setting (2):

$$
n(r)=\frac{2 \cdot \pi \cdot r}{b+g}
$$

With this, Equation 1 can be integrated directly to yield Eq. 3

$$
B E L=\frac{(2 \cdot \pi)^{2}}{\cos \phi} \cdot\left(\frac{R_{2}^{3}-R_{1}^{3}}{3 \cdot(b+g)^{2}}\right)
$$

At this point, attention must be directed to define an operating parameter used through the research, i.e. the no-load power. No-load power refers to the power used by the refiner for purposes other than changes in fibre morphology. The LC (low consistency) refiner no-load power has been estimated to $20-35 \%$ of the total refiner motor power, (Dietermann and Roux, 2005). During the process of defibration, radial compression collapses the lumen, the cross section bound by fibre cell wall, which enhances paper smoothness and sheet uniformity in paper making (Page and Grace, 1967). In this work, effect was observed of plate pattern type on the size quality of fibres produced. The purpose of this research was:

(1) to compare on-site efficiency of three types of plate pattern,

(2) to understand differences in time series performance of these types of plate pattern in a disc type refiner.

\section{MATERIAL AND METHODS} 2. MATERIJAL I METODE

In this research refiner plates with different pattern design (TYPE 1, TYPE 2 and TYPE 3) were used and the fibre-size i.e. fibre-quality distribution was evaluated. Wooden raw material composed of $80 \%$ softwood and $20 \%$ hardwood was processed at 1500 $\mathrm{rpm}$. The distance between refiner plates was automatically optimized according to tool wear. Samples of fibres were taken from belt conveyer at the interval of 2 , 10, 30, 200, 350, 500, 650, 800, 950, 1100, 1250 and 1378 hrs. Samples were stored in laboratory plastic bags to provide constant relative humidity and marked by number, time and date. The weight of specimens were scaled for $30 \mathrm{~g}$ and homogenized at $20^{\circ} \mathrm{C}$ and 60 $\%$ relative humidity for 24 hours. For size analysis, the cascade laboratory sieving machine was employed (Figure 1). The sieves with different sizes $(2 ; 1 ; 0.5$; $0.25 ; 0.16 ; 0.08 \mathrm{~mm}$ ) were used to determine the volume of fibres on sieve of each type of sieve opening. The fibres were sieved for 50 minutes and the weight of fibres from each section was determined. This laboratory process was used for all samples separately. Data were mathematically evaluated and listed in 


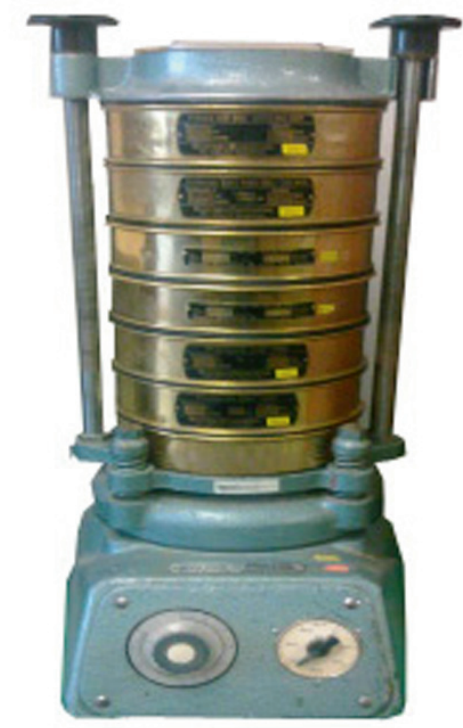

Figure 2 Laboratory cascade sieve

Slika 2. Laboratorijsko kaskadno sito

graphs. Although the size range was very wide, the solution of size distribution in time was included as well as the quantity of particles by means of descriptive statistics of the total produced amount of each fibre type by each tested plate. The trends were evaluated using software MS Excel and then software STATISTICA.10 to obtain the total amount of fibre type produced by each tested refiner plate. The ANOVA test with Duncan's post-hoc test was employed to determine statistically significant differences between the effects of refiner plates.

Quantity of fibres with specified size (Q) was calculated using equation (4), where $m_{\mathrm{n}}$ is the weight of fibres on $n^{\text {th }}$ sieve in a cascade starting from the top, and $m_{0}$ is the total weight of the fibres.

$$
Q=\frac{m_{n}}{m_{0}} \cdot 100[\%]
$$

\section{RESULTS}

\section{REZULTATI}

The research provided solid ground for size-evaluation in time series, and size distribution of fibres produced by each refiner plate type was reported. Results in figures represent trends of change in fibre size with time and also relative quantity of fine fibre produced by different refiner plates. For plate Type 1 (Figure 3), in the time range of 500-800 hrs, the relative amount of dust fibres (undesirable) was found to be minimum, whereas other desired fibre sizes of 0.16 to 1 were found to be at a maximum relative amount. So, the range between 500 and $900 \mathrm{hrs}$ can be considered as optimum performance time for the refiner plate.

Fibres processed by TYPE 2 (Figure 4) were found to be in the desired size in time ranging between 300 and 900 hours, the relative amount of dust fibres (bottom) shows a steep fall in the first section of operation and rise after 900 hours. The amount of fibres with dimension of 0.08 to $1 \mathrm{~mm}$ showed a decrease during the whole duration of operation. Larger particles (above $1 \mathrm{~mm}$ ) showed a steady tendency with the same percentage as at the beginning. Their share during the production is up to $8 \%$.

Type 3 plate pattern (Figure 5) is represented by decreasing quantity of dust fibres whose size is smaller than the last sieve i.e. $0.08 \mathrm{~mm}$ up to $600 \mathrm{hrs}$. The quantity of fibres with the size of 0.08 to $0.016 \mathrm{~mm}$ is increased or constant in the second half of the production, as well as the quantity of particles with dimensions greater than $0.5 \mathrm{~mm}$. Although these facts are not convincing for mill efficiency, the positive results are achieved for fibres concerned. It can be concluded that the quantity of high quality size fibres are used in a steady range throughout the production time up to 750 hours.

Total performance of the refiner plates were also evaluated as mean values of the total produced fibres along the refiner life span (see Table 1). Considering
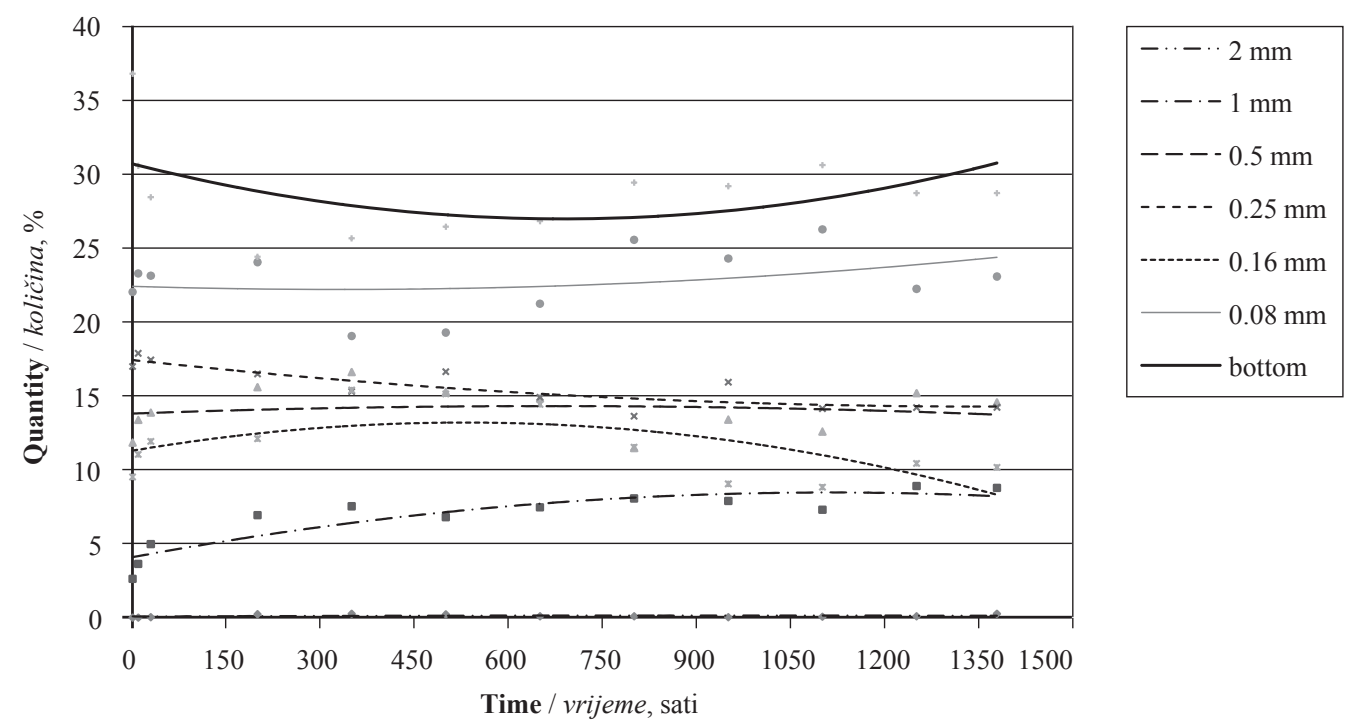

Figure 3 Fibre-sizes in time, processed by TYPE 1 in tool life cycle (trends of results are included)

Slika 3. Veličina vlakanaca u ovisnosti o vremenu uzimanja uzorka; za proizvodnju vlakanaca primijenjena je ploča TYPE 1 tijekom životnog ciklusa alata (uključena je trend linija rezultata) 

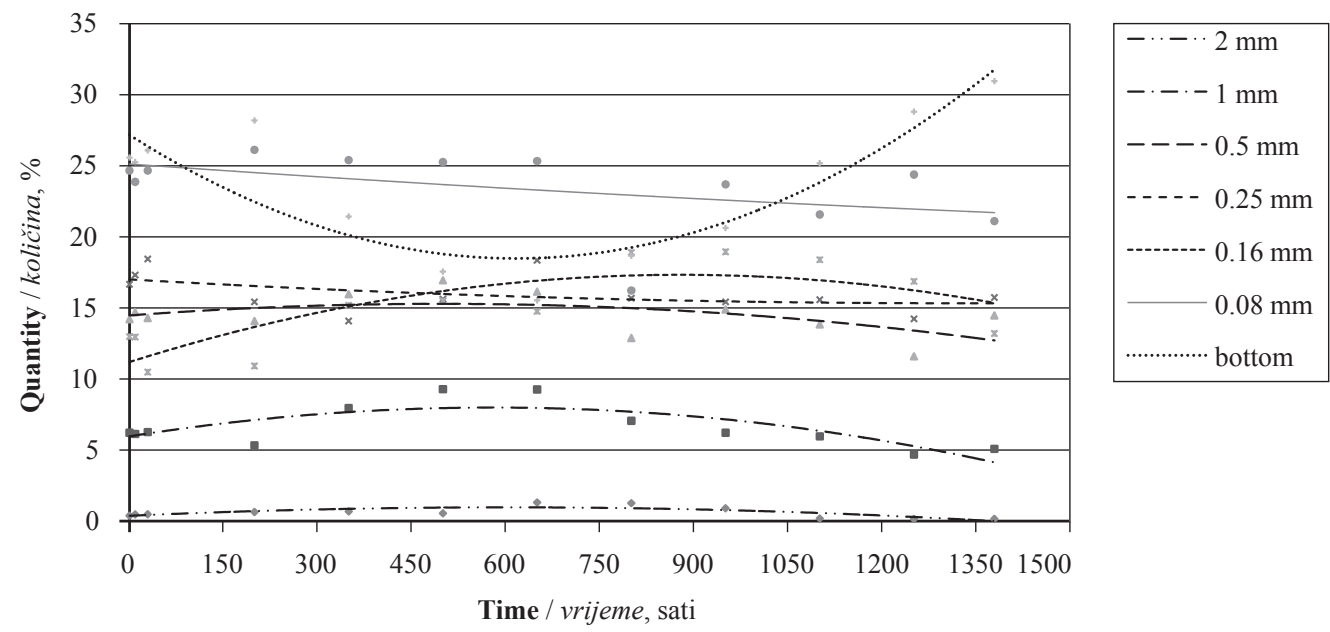

Figure 4 Fibre-sizes in time, processed by TYPE 2 in tool life cycle (trends of results are included)

Slika 4. Veličina vlakanaca u ovisnosti o vremenu uzimanja uzorka; za proizvodnju vlakanaca primijenjena je ploča TYPE 2 tijekom životnog ciklusa alata (uključena je trend linija rezultata)

fibres on $1 \mathrm{~mm}$ sieve, TYPE 1 and TYPE 2 produced the same amount of fibres (ANOVA; $p>0.05$ ). At the same time, TYPE 3 produced a higher amount of $1 \mathrm{~mm}$ fibres compared to TYPE 1 (ANOVA; $p<0.05$ ). The plates delivered the same amount of fibres considering $0.5 \mathrm{~mm}$ sieve. On the other hand, the dimension of 0.25 showed insignificant differences between the total amount of produced fibres considering all types of refiner plates. All tested Types performed with fibres amount to around $15 \%$ (ANOVA, $p>0.05$ ). With the use of $0.16 \mathrm{~mm}$ sieve, different amounts were produced by TYPE 3 and TYPE 1 (ANOVA; $p<0.05$ ). Fibre production of TYPE 3 was lower by $1.5 \%$. Fibre production on 0.08 sieve was higher by $3.5 \%$ with TYPE 1 compared to TYPE 3 (ANOVA; $p<0.05$ ). Interestingly, the dust fibres on the last sieve (Bottom) were produced in the same amount of $29 \%$ by TYPE 3 and TYPE 1 , while TYPE 2 showed a significantly lower production of fibres (ANOVA; $p<0.05$ ).

According to results, the plate pattern has significant influence on fibre-quality during its lifetime. With
TYPE 1 and TYPE 2, longer life span and higher volume of high quality fibres were obtained, however low quality dust fibres were also produced in considerable amount. TYPE 2 and TYPE 1 have the highest amount of high quality fibres (sieve range 0.08 to $0.25 \mathrm{~mm}$ ) with no significant change until the end of the tool life span. Nevertheless, the percentage share of the high quality fibres is not constant during the whole processing time. Results with TYPE 1 showed a decreasing tendency of high quality fibres during the whole operation. On the other hand, the lifetime of refiner plates was longer than in case of the last Type. Although TYPE 3 has the shortest production time, the quality of fibres is high. The share of the fibres with high quality is constant and high from the beginning to the end of lifetime. On the other hand, the lifetime limits its recommendation for future use. With respect to the presented facts, TYPE 2 and TYPE 1 are considered as the best option for the use in the process, the lifetime is long and the volume of high quality fibres is high throughout the production. Despite the short lifetime,

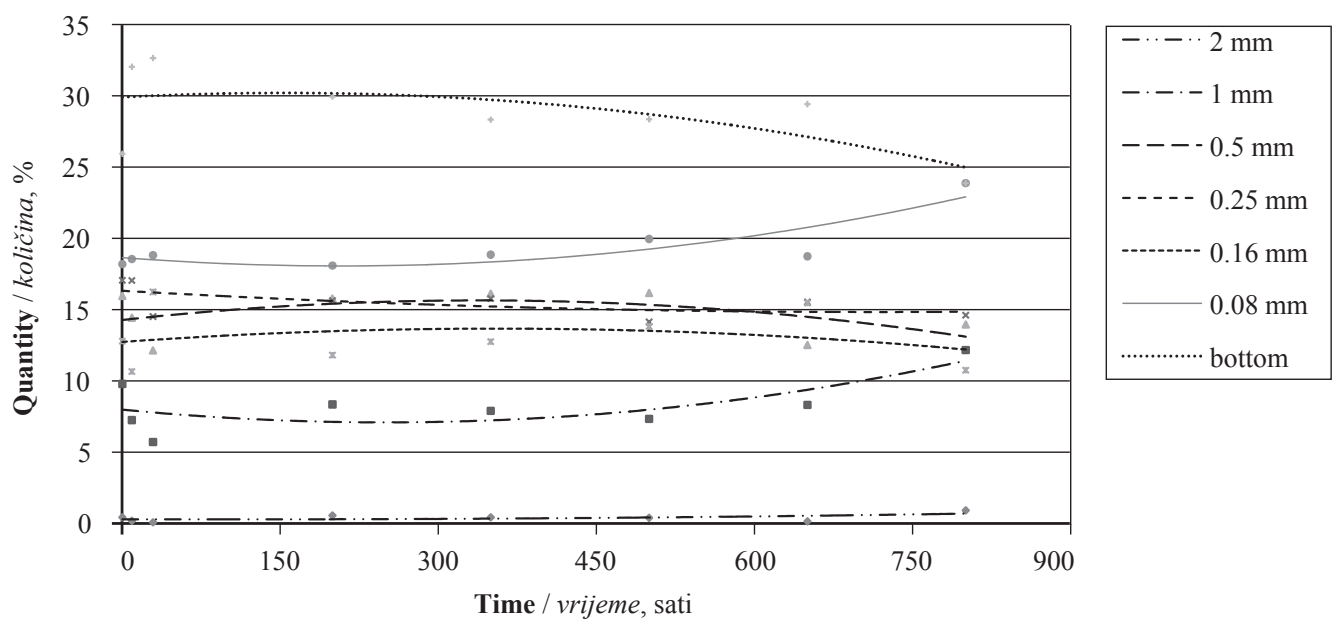

Figure 5 Fibre-sizes in time, processed by TYPE 3 in tool life cycle (trends of results are included)

Slika 5. Veličina vlakanaca u ovisnosti o vremenu uzimanja uzorka; za proizvodnju vlakanaca primijenjena je ploča TYPE 3 tijekom životnog ciklusa alata (uključena je trend linija rezultata) 
Table 1 Descriptive statistics of the total amount of fibres considering the total amount of fibres obtained in refiner plate life span Tablica 1. Deskriptivna statistika ukupne količine vlakanaca određenih dimenzija u ukupnoj količini proizvedenih vlakanaca tijekom životnog ciklusa diska za razvlaknjivanje

\begin{tabular}{|c|c|c|c|c|c|c|}
\hline \multicolumn{7}{|c|}{ TYPE $1, \%$} \\
\hline & $1 \mathrm{~mm}^{\mathrm{p}}$ & $0.5 \mathrm{~mm}^{\mathrm{r}}$ & $0.25 \mathrm{~mm}^{\mathrm{t}}$ & $0.16 \mathrm{~mm}^{\mathrm{u}}$ & $0.08 \mathrm{~mm}^{\mathrm{w}}$ & Bottom $^{x}$ \\
\hline mean & 6.79 & 14.08 & 15.67 & 11.67 & 22.80 & 28.81 \\
\hline $\min$ & 2.68 & 11.51 & 13.66 & 8.87 & 19.07 & 24.41 \\
\hline $\max$ & 8.95 & 16.63 & 17.90 & 15.42 & 26.26 & 36.76 \\
\hline st.dev & 1.98 & 1.56 & 1.44 & 2.28 & 2.20 & 3.15 \\
\hline \multicolumn{7}{|c|}{ TYPE 2, \% } \\
\hline & $1 \mathrm{~mm}^{\mathrm{p}, \mathrm{q}}$ & $0.5 \mathrm{~mm}^{\mathrm{r}, \mathrm{s}}$ & $0.25 \mathrm{~mm}^{\mathrm{t}}$ & $0.16 \mathrm{~mm}^{\mathrm{u}, \mathrm{v}}$ & $0.08 \mathrm{~mm}^{\mathrm{w}}$ & Bottom $^{y}$ \\
\hline mean & 6.53 & 14.40 & 15.94 & 14.82 & 23.41 & 23.54 \\
\hline $\min$ & 4.59 & 11.50 & 13.98 & 10.39 & 16.12 & 15.43 \\
\hline $\max$ & 9.19 & 16.84 & 18.33 & 18.84 & 26.00 & 30.83 \\
\hline st.dev & 1.50 & 1.44 & 1.40 & 2.93 & 2.74 & 4.83 \\
\hline \multicolumn{7}{|c|}{ TYPE 3, \% } \\
\hline & $1 \mathrm{~mm}^{\mathrm{q}}$ & $0.5 \mathrm{~mm}^{\mathrm{s}}$ & $0.25 \mathrm{~mm}^{\mathrm{t}}$ & $0.16 \mathrm{~mm}^{\mathrm{v}}$ & $0.08 \mathrm{~mm}^{\mathrm{y}}$ & Bottom $^{x}$ \\
\hline mean & 8.32 & 14.62 & 15.52 & 13.01 & 19.37 & 28.81 \\
\hline $\min$ & 5.68 & 12.12 & 14.11 & 10.63 & 18.07 & 23.86 \\
\hline $\max$ & 12.14 & 16.15 & 17.04 & 16.22 & 23.86 & 32.65 \\
\hline st.dev & 1.93 & 1.64 & 1.10 & 2.05 & 1.90 & 2.93 \\
\hline
\end{tabular}

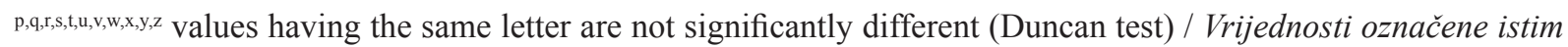
slovom značajno se ne razlikuju

TYPE 3 is then recommended due to constant fibre quality, which was also high at the start of production, compared to TYPE 1 and TYPE 2, and did not significantly fall during the production. Considering TYPE 1 compared to TYPE 2, high quality fibres were produced at the beginning, however with decreasing tendency during the production. The quantity of highquality fibres reached the peak in time ranging between 200 and 500 hours and after that its quantity declined. Since plate pattern design includes numerous mathematical and technical niceties, more research is required to understand the behaviour of each plate.

\section{CONCLUSIONS}

\section{ZAKLJUČAK}

1. In this study, three Types of refiner plates were successfully compared in terms of mean values of fibre sizes produced along the life span. Various trends and different plate life spans were presented.

2. The results show that TYPE 1 and TYPE 2 plates provide very similar total amount of fibres since ANOVA shows difference only in the amount of fibres on the bottom of cascade sieve i.e. dust particles.

3. TYPE 3 is found to provide constant fibre quality, which does not significantly fall during the life span of the plate. On the other hand, the total life span of the plate is lower than that of TYPE 1 and TYPE 2.

\section{Acknowledgments - Zahvala}

This research was supported by the European Social Fund and the state budget of the Czech Republic, project "The Establishment of an International Research Team for the Development of New Wood-based Materials" reg. no. CZ.1.07/2.3.00/20.0269

\section{REFERENCES}

5. LITERATURA

1. Antensteiner, P., 2008: Conical refiner plates with logarithmic spiral Type bars. US 7,398,938 B2.

2. Dietermann, P.; Roux, J. C., 2005: A study of disc refiner running in no-load conditions, Cellulose Chemistry and Technology, 39(5-6): 459-471.

3. Gingras, L., 2011: Mechanical pulping refiner plate having curved refining bars with jagged leading sidewalls and method for designing plates. US 7,900,862 B2.

4. Gingras, L., 2012: Tooth refiner plates having V-shaped teeth and refining method. EP $1806451 \mathrm{~B} 1$.

5. Lumiainen, J., 2010: Refining of chemical pulp, in: Papermaking Part 1, Stock Preparation and Wet End., pp. 105-122.

6. Page, D. H.; De Grace, J. H., 1967: Delamination of fibre walls by beating and refining, Tappi Journal, 50(10): 489 $-495$.

7. Rowell, R. M., 2012: Handbook of Wood Chemistry and Wood Composites, 2nd edition. http://dx.doi.org/10.1201/b12487

8. Savujz'irvi, P.; Liifgren,, M., 1999: High consistency dam-less refiner plate for wood fibres. US005944271A.

9. Wasikowski, P., 1996: Rough edged refiner plate cutter bars. USOO5492548A.

10. ***Andritz paper mill services, 2011. Case study, Refiner Plate Design.

\section{Corresponding address:}

Assoc. prof. Pavel KRAL, Ph. D.

Mendel University in Brno

Faculty of Forestry and Wood Technology

Zemědělská nr. 3

61300 Brno, CZECH REPUBLIC

e-mail:kral@mendelu.cz 